\title{
Max Martins e o suplemento A Folha do Norte
}

\author{
Max Martins and the A Folha do Norte literary Review
}

Lilia Silvestre CHAVES*

Universidade Federal do Pará (UFPA)

\begin{abstract}
RESUMO: O presente ensaio narra o percurso de evolução da moderna poesia paraense, especialmente dos membros da Academia dos Novos, no Suplemento literário "Arte-Literatura", do jornal Folha do Norte, dirigido por Haroldo Maranhã entre os anos de 1946 e 1951, em Belém. Relata o início da Academia dos Novos, a ruptura com a escola de poesia parnasiana e o consequente mergulho na estética modernista. Revê as primeiras publicações dos jovens escritores paraenses no Suplemento, de modo a apresentar ao público a trajetória de inserção das letras paraenses na modernidade nacional, com ênfase no retrato da história de amizade que uniu Max Martins e Benedito Nunes.
\end{abstract}

PALAVRAS-CHAVE: Academia dos Novos. Max Martins. Benedito Nunes. Folha do Norte

ABSTRACT: This text portrays the evolution of the modern poetry made in Pará, focusing on the members of the Academia dos Novos, through the publications in the literary journal called "Art-Literature", issued by the local newspaper, Folha do Norte. The journal was directed by Haroldo Maranhão, between 1946 and 1951, in Belém. The text discloses the beginnings of the Academia dos Novos, its breaking up with the old school of poetry that reigned in Belém at the time, and its subsequent imersion in the modern aesthetics. It also reviews the first publications of the young generation of poets, actively writing in Belém, in order to present the route taken by the northern literary community into national modernization. Finally, it focuses on the story of the friendship relating Max Martins and Benedito Nunes.

KEYWORDS: Academia dos Novos. Max Martins. Bendito Nunes. Folha do Norte

Recebido em 13 de dezembro de 2016. Aprovado em 15 de dezembro de 2016.

\footnotetext{
${ }^{*}$ Lília Silvestre Chaves é professora do Programa de Pós-Graduação em Letras da UFPA, Belém, Pará, e doutora em Estudos Literários pela UFMG. E-mail: palpebras@uol.com.br.
} 


\section{Nossa amizade é um grande encontro}

Uma história tantas vezes contada, sempre que se evoca aquele tempo de longas distâncias e de poucos contatos entre os vários estados brasileiros, é do Suplemento dominical da Folha do Norte que para a evolução da literatura paraense. Dentro dele narra-se uma fase da história de muitos escritores e paraenses, inclusive a do poeta Max Martins.

Antes, porém, de conhecer o grupo de rapazes que, em 1946, estariam unidos aos outros intelectuais de Belém, como colaboradores do futuro Suplemento da Folha do Norte, Max Martins, então com 17 anos, Alonso Rocha (seu primo) e Jurandyr Bezerra reuniram-se e fundaram a "Academia dos Novos". A intenção era discutir poesia e divulgar suas ideias e seus poemas na Amazônia, a Revista da Academia dos Novos, manuscrita e "editada" em papel almaço, de cujo primeiro número temos precioso registro. 
Figura 1 - Amazônia - Revista da Academia dos Novos, ano 1, n. 1, mar. 1943.

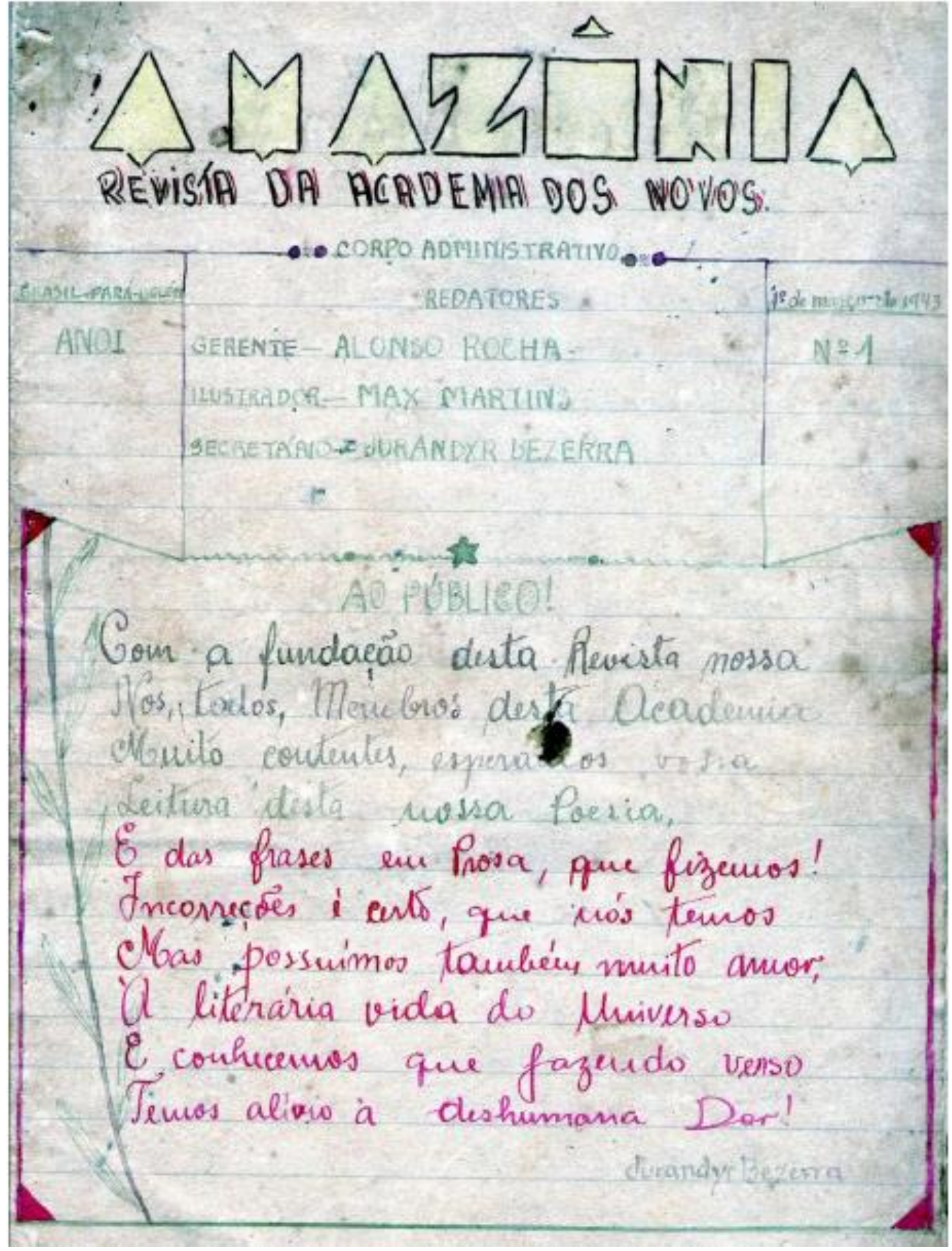

Fonte: Acervo de Alonso Rocha (ALENCAR, 2011, p. 51).

Em agosto desse mesmo ano de 1943, a vida de Max Martins entrelaçou-se com a de Benedito Nunes. A partir de então, entre os dois instalou-se uma "relação intersubjetiva, como se diz no jargão filosófico" (NUNES, 2012, p. 161). Para Benedito, falar de Max era como falar de si mesmo: "Esse tu, muito próximo de mim, está comigo identificado", (2012, p. 161) revelou, comovido, em um texto destinado a ser lido na 
ocasião de uma homenagem a Max Martins, efetuada pela Universidade Federal do Pará. Para mim, escrever sobre Max Martins é também escrever sobre Benedito Nunes, aquele amigo que se torna parente por escolha. É citar Benedito Nunes. É ele que, em um de seus textos memorialistas, "Nossos Encontros", descreve o momento em que se conheceram.

\begin{abstract}
Encontramo-nos quando éramos jovens; juntos ingressamos na maturidade e [...] envelhecemos. Nossa amizade é um grande encontro que começou, salvo engano, em 1943, quando eu tinha 13 anos de idade.

Não sei o dia. Por iniciativa de Haroldo Maranhão, vieram à minha casa na Gentil Bittencourt, então $n^{\circ} 25$, naquele mesmo ano e no mesmo instante, os três membros da Associação dos Novos ${ }^{\dagger}$, àquela época existente, Alonso Rocha, Jurandir Bezerra e Max Martins para reunir-se a nós dois - eu e Haroldo - numa nova entidade a ser fundada, a Academia dos Novos, que copiava em tudo a organização da Academia Brasileira de Letras, segundo os moldes divulgados pelo Anuário dessa mesma instituição que aquele meu amigo havia recebido do Rio por uma mala do navio Ita da Companhia Nacional Costeira. Max trabalhava então no Banco do Pará; fundou e ocupou a cadeira Machado de Assis do nosso sodalício. A Academia dos Novos era progressista em política e reacionária em arte. Todos nós, sem exceção, repudiávamos o Modernismo e o Estado Novo golpista de Getúlio Vargas, surgido em 37. O acadêmico Max Martins seria o editor de um dos dois primeiros livros do acadêmico Benedito Nunes, a coletânea de poesia "O Olho d'Água"; acho que não chegou a copiar o segundo, de contos, "Nimbos do Céu", nome de extremo mau gosto. Editar significava, para nós, simplesmente datilografar. Max copiou pacientemente em vermelho, usando a máquina de escrever do Banco do Pará, "O Olho d'Água" (NUNES, 2012, p. 161).
\end{abstract}

Esses jovens citados por Nunes, todos nascidos nos últimos anos da década de 20 e nos primeiros da década de 30 do século XX, portanto com menos de 20 anos Benedito Nunes (1929-2011), Haroldo Maranhão (1927-2004), Max Martins (19262009), Alonso Rocha (1926-2011) e Jurandyr Bezerra (1928-2013) -, que "brinca[vam] a sério de literatura", iniciaram uma espécie de luta poética em Belém, que parecia um retrocesso na história da poesia paraense: todos eles - que se uniram em uma academia literária, à qual deram o nome (que lhes pareceu muito original) de Academia dos Novos - cultivavam a poesia parnasiana de Olavo Bilac e a simbolista de Cruz e Souza, com rimas e versos escandidos. Todos desdenhavam a poesia moderna e, dos poetas paraenses mais antigos, que tinham vivido os ares do Modernismo brasileiro, só respeitavam a obra de Bruno de Menezes (1893-1963). Queriam, com esse encontro organizado por Haroldo Maranhão, fundar uma Academia, exatamente igual à

\footnotetext{
${ }^{\dagger}$ Pela reprodução da revista Amazônia, Max Martins, Alonso Rocha e Jurandyr Bezerra tinham fundado uma "Academia", não uma Associação, como diz Benedito Nunes nesse texto de memória.
} 
Academia Brasileira de Letras, da qual tinham estudado o último Anuário, copiando a forma - "Cadeiras, patronos, discursos de recepção e posse, fardão, símbolo - $A d$ imortalitatem - de todas essas partes do sistema acadêmico, que sabíamos de cor, falamos aos ilustres visitantes. Quem haveria de discordar do modelo proposto?", pergunta Nunes, em "Crônica de uma Academia" (2012, p. 157). Como todos eles pretendiam lutar contra o Modernismo, pensavam não haver melhor plano de ataque do que se espelhar nos membros da Academia Brasileira de Letras (antes que esta acolhesse Manuel Bandeira). No ano anterior, Haroldo Maranhão escrevera uma crítica à poesia de Bandeira e Drummond, os quais acusava de cometer verdadeiro atentado à poesia - texto lido em voz alta em reunião do Grêmio Cívico do Colégio Moderno (do qual era presidente) e publicado, depois, na Folha do Norte, e Benedito Nunes era autor de uma sátira em versos contra os mesmos poetas. Segundo eles, Drummond e Bandeira escreviam os versos que escreveram porque não sabiam rimar e metrificar.

Revisto mais tarde com humor ou nostalgia, o primeiro olhar entre duas pessoas que depois se tornariam grandes amigos adquire uma dimensão mítica e inscreve-se no movimento mais geral das descobertas pessoais. Os relatos de encontros integram-se às biografias, transformando-se em situações vivas e transportando o leitor para o espaçotempo mágico da memória. As descrições que fixam o primeiro encontro com alguém famoso posteriormente - transpõem para uma cena simbólica o momento inesquecível do "quando eu o vi pela primeira vez". É o olhar face a face com a memória.

Visto do topo da escada que subiam, e onde, como anfitrião, me encontrava juntamente com Haroldo, os nossos três convidados me pareceram bizarros. Sérios, de paletó, as passadas repercutindo fortes nos degraus de madeira, o mais à frente um brancão magro, queixo agudo e com marcas de espinha, vestido num jaquetão branco, de onde aflorava a faixa estreita de uma gravata vermelha - os dois outros, mais atrás, morenos, os três subiam solenes, institucionais, o espírito coeso em marcha da Associação dos Novos que encaravam naquele momento (NUNES, 2012, p. 157).

Naquela primeira reunião preparatória, entre outras deliberações, decidiram que a sede provisória oficial seria a sala da casa das tias de Benedito Nunes (onde ele mesmo morava), pelas “condições ótimas para a instalação condigna da ilustre sociedade" (NUNES, 2012, p. 158). Também escolheram seus patronos, cabendo a Max Martins o escritor Machado de Assis ${ }^{\ddagger}$. Aos poucos, novos membros foram sendo admitidos, e as sessões sucederam-se entre leituras e discussões sobre livros, a maioria

\footnotetext{
\$ O patrono de Haroldo Maranhão era Humberto de Campos, o de Alonso Rocha, Castro Alves, o de Jurandyr Bezerra, Olavo Bilac, e Benedito Nunes ficou com Rui Barbosa.
} 
emprestada da biblioteca de Haroldo Maranhão. Às vezes, publicavam seus escritos na coluna “Os que se iniciam”, que o jornal Folha do Norte (do avô de Haroldo Maranhão) criara para os membros da Academia.

A Academia teve um fim repentino, quando Max Martins, que se converteu ao Modernismo, “imprevistamente, deu um morra à Academia, [e] retirou-se, estabanado, do sacrossanto recinto, indo sentar-se num banco público fronteiro à casa, à espera que a sessão terminasse" (NUNES, 2012, p. 160).

Pouco tempo depois do fim da Academia dos Novos, apareceu o Suplemento da Folha e esses mesmos "novos" tiveram oportunidade de publicar seus poemas no Suplemento dominical de um jornal importante de Belém, na época. Criado e editado por Haroldo Maranhão, um dos membros da Academia e neto do dono do jornal, o Suplemento uniu os jovens ex-acadêmicos aos intelectuais da geração mais velha (do final dos anos 30), como colaboradores e principais leitores, traduzindo, como um campo neutro, "durante cinco anos [de agosto de 1946 a janeiro de 1951], o espírito comum do grupo maior, afinado pela leitura dos mesmos poetas, ficcionistas e filósofos e pela admiração votada aos mesmos artistas" (NUNES, 2001, p. 16). E mais, ao publicar poetas e escritores do Norte lado a lado com os do Sul, também colaboradores do Suplemento, inseriu sutilmente a província no movimento mais amplo da modernidade nacional ${ }^{\S}$.

\section{Posição e destino da literatura paraense}

Organizada por Peri Augusto, uma enquete entre os intelectuais de Belém questionava sobre a posição e o destino da literatura paraense. Os entrevistados deveriam responder: I - Que pensa da chamada geração moderna de nosso Estado? II Existe na atual geração literária paraense, alguma ligação e respeito às tradições da nossa vida cultural? III - Como você vê o futuro das Letras no Pará, no Brasil e no mundo?

O quarto entrevistado, Bruno de Menezes, poeta responsável pela inovação da poesia paraense, com o longo poema-ritmo "Batuque" (1931), respondeu: “É uma farsa muito vazia de sentido falar-se em 'Geração Moderna' do nosso estado". Mas, "se moderno quer dizer da hora presente", poderiam ser lembrados os nomes "de um Ruy

\footnotetext{
§ É importante lembrar que, além do jornal, os ex-membros da Academia dos Novos passaram a frequentar outros "salões", como o Café Central, a encontrar o professor Francisco Paulo Mendes, que se tornou uma espécie de mentor do grupo, e incorporaram ao grupo os poetas paraenses Ruy Barata, Paulo Plínio Abreu e Mário Faustino. Mais tarde, o encontro com Bob Stock e com Max Boudin também foi decisivo para sua história literária.
} 
Guilherme Barata, um Paulo Plínio de Abreu, um Benedito Nunes, ou os de Haroldo Maranhão, Jurandir Bezerra, Max Martins, embora ainda presos aos complexos liricamente emotivos”. Quanto a escritores, teatrólogos, ensaístas, pensadores em geral, Bruno cita "valores distintos como um Francisco Mendes, um Cécil Meira, um Raimundo Moura, um Cléo Bernardo” (MENEZES, 1947, p. 3).

Figura 2 - A palavra de Max Martins. Enquete "Posição e destino da Literatura".

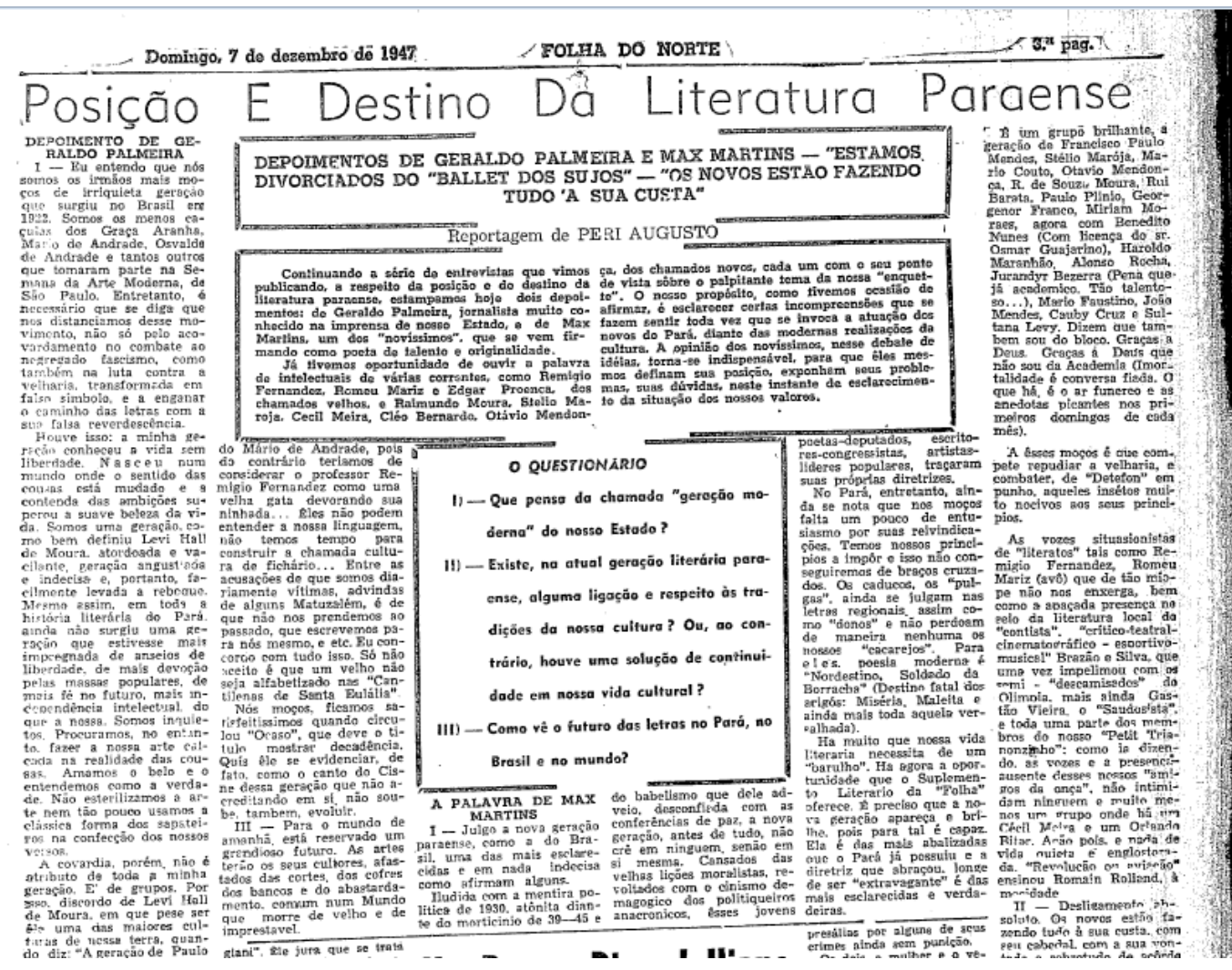

Fonte: Suplemento Artes-Letras. Folha do Norte. 1947, p. 3.

Por sua vez, Max Martins, “um dos 'novíssimos', que se vem firmando como poeta de talento e originalidade" (AUGUSTO, $7 \mathrm{dez}$ 1947, p. 3), disse acreditar que a geração paraense era uma das mais esclarecidas e em nada indecisa, como alguns tentaram afirmar, apesar de iludida com a "mentira política de 1930" e atônita com o “morticínio de 29-45", a nova geração não crê em ninguém, "senão em si mesma", e traçou "suas próprias diretrizes". Na resposta à segunda pergunta, Max foi taxativo quanto à ligação dos novos com os velhos: desligamento absoluto. Os novos estão fazendo tudo à sua custa, com seu cabedal, com sua vontade e, sobretudo, de acordo com o que a época lhe ensinou". E finalizou com um tom otimista diante do futuro das Letras no Pará: segundo ele, "depois da guerra a cultura deixou de ser francesa, alemão, 
russa, inglesa. Apoderou-se dela um sentido universal, assim como que pedindo desculpas por seis anos de 'sangue suor e lágrimas'. E isto é promissor”.

Figura 3 - Um só número da revista Encontro (1948).

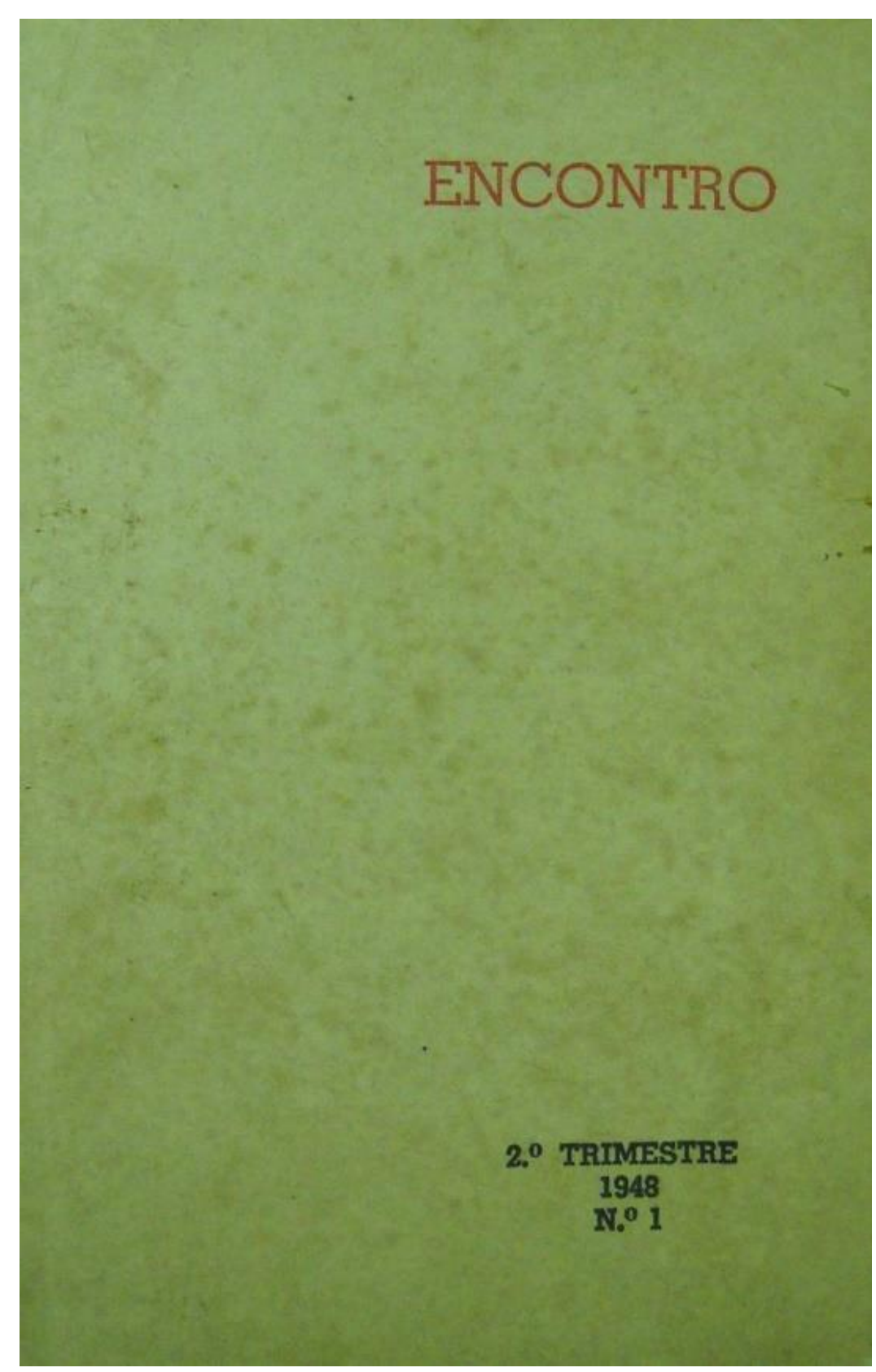

Fonte: Acervo da Profa. Anunciada Chaves.

Além dos cafés e dos jornais, as revistas também congregaram as ideias da época. Encorajados pelo sucesso do "Suplemento" e pela facilidade de impressão oferecida pelo jornal, "eu e Max, com Haroldo e Mário Faustino publicamos uma revista literária chamada Encontro, [...]. Não passou do primeiro número". Nelson Sanjad relata a história da revista natimorta (como lhe contou Benedito Nunes): "Havia a ideia de fazer a revista. Aproveitando a ausência de Haroldo, em viagem ao Rio de 
Janeiro, eu e Mário Faustino fomos numa tarde de sábado às oficinas da Folha do Norte. Juntamos vários textos, fizemos um amarrado e apressamos a revista. Saiu uma coisa mal feita... Era paralela ao Suplemento! Mandamos urgente para o Haroldo, pelo Correio. Uma semana depois recebo um telegrama do Rio: 'Revista uma merda"" (SANJAD, 2001, p. 102).

\section{Max Martins entre os Dez Poetas Paraenses}

Para contar esse trecho da história, além de palavras de Benedito Nunes, é preciso fazê-lo personagem, como guardião do arquivo em que repousam alguns dos documentos que ficaram dessa época de início de suas vidas como escritores.

No final de 1951, Haroldo Maranhão (seu editor e organizador), antes de sair em viagem de férias para Fortaleza, nomeou Ruy Barata seu substituto e deixou duas reportagens organizadas para serem publicadas no "Suplemento" durante sua ausência. A primeira delas ${ }^{* *}$ era uma antologia de dez poetas paraenses - todos pertencentes à nova geração de intelectuais, que frequentava o Café Central -, da qual o próprio Haroldo, o "Bené", o Max, o Mário e o Ruy Barata faziam parte.

Questionado sobre essa reportagem e sobre a crítica que a ela se seguiu, Benedito Nunes coçou levemente a cabeça, franziu a testa: onde estaria o jornal em que foi publicada a crítica? Foi buscar a sua coleção de "Suplementos" da Folha, arquivados cuidadosamente no armário de canto da Bicom ${ }^{\dagger \dagger}$ (junto aos do Jornal do Brasil, aos três exemplares da revista Norte, e a outros jornais esparsos, revistas e pastas contendo cartas e artigos variados). Abriu o "Suplemento" n. ${ }^{\circ} 163$ com muito cuidado: o papel dos jornais, muito amarelo, ameaçava desfazer-se. A antologia ocupava as quatro páginas: "Dez poetas paraenses", seleção e notas de Ruy Guilherme Barata. Um poeta em cada coluna e uma página inteira para Ruy Barata. Havia uma foto de cada poeta (eram eles, Alonso Rocha, Benedito Nunes, Cauby Cruz, Ruy Guilherme Barata, Floriano Jaime, Haroldo Maranhão, Mário Faustino, Maurício Rodrigues, Max Martins e Paulo Plínio Abreu), algumas notas biográficas e os poemas escolhidos.

\footnotetext{
** A outra reportagem era uma antologia reunindo "Sete contistas paraenses", publicada no Suplemento de 31 de dezembro de 1951.

† Biblioteca complementar, como chamava a essa parte da sua biblioteca, em que guardava o arquivo de cartas, revistas e jornais.
} 
Figura 4 - "Suplemento Arte-Literatura", de 24 de novembro de 1950, p. 1.

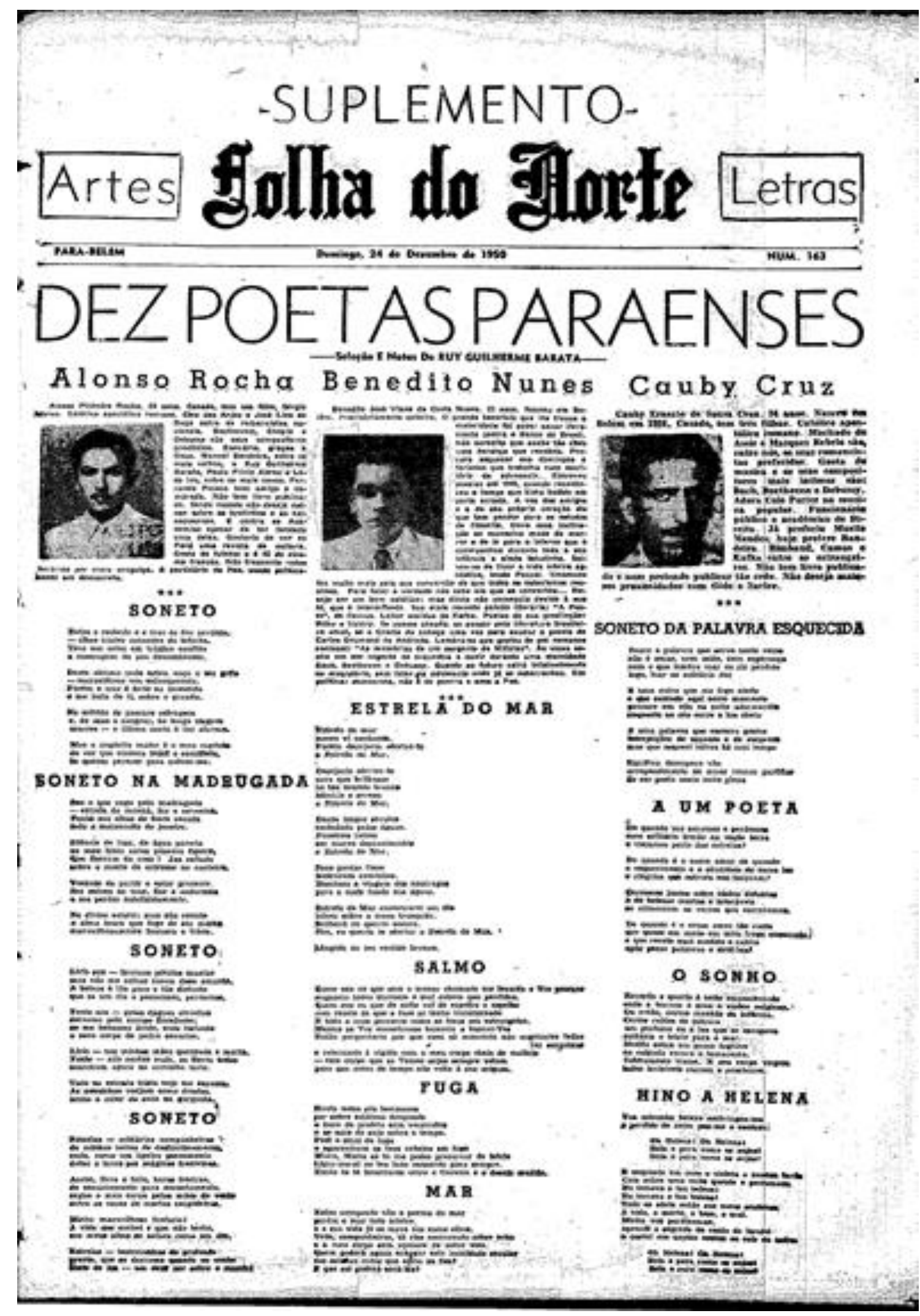

Fonte: Arquivo pessoal. 
Figura 5 - "Suplemento Arte-Literatura", de 24 de novembro de 1950, p. 2.

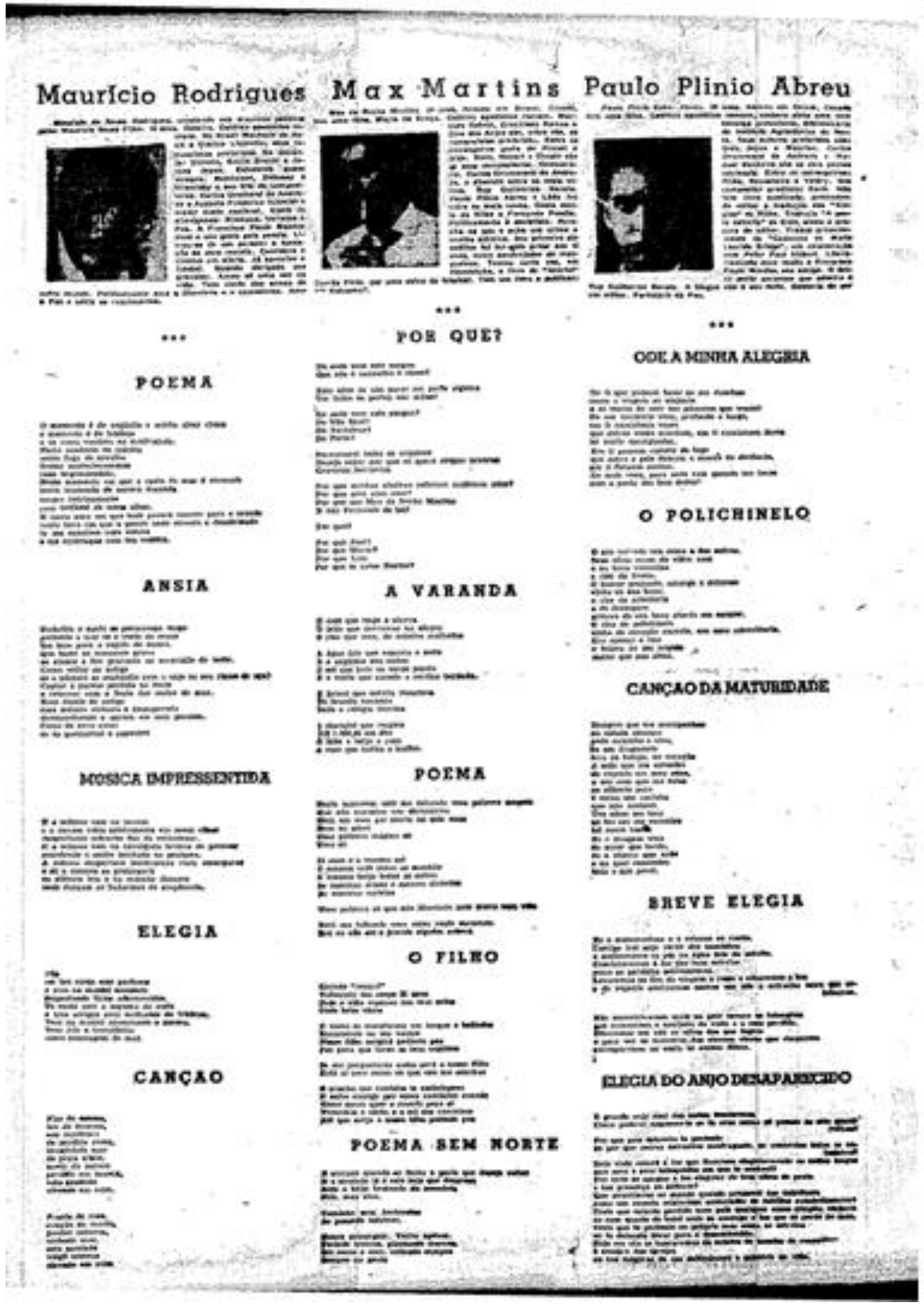

Fonte: Arquivo pessoal. 
Figura 6 - "Suplemento Arte-Literatura", de 24 de novembro de 1950, p. 3.

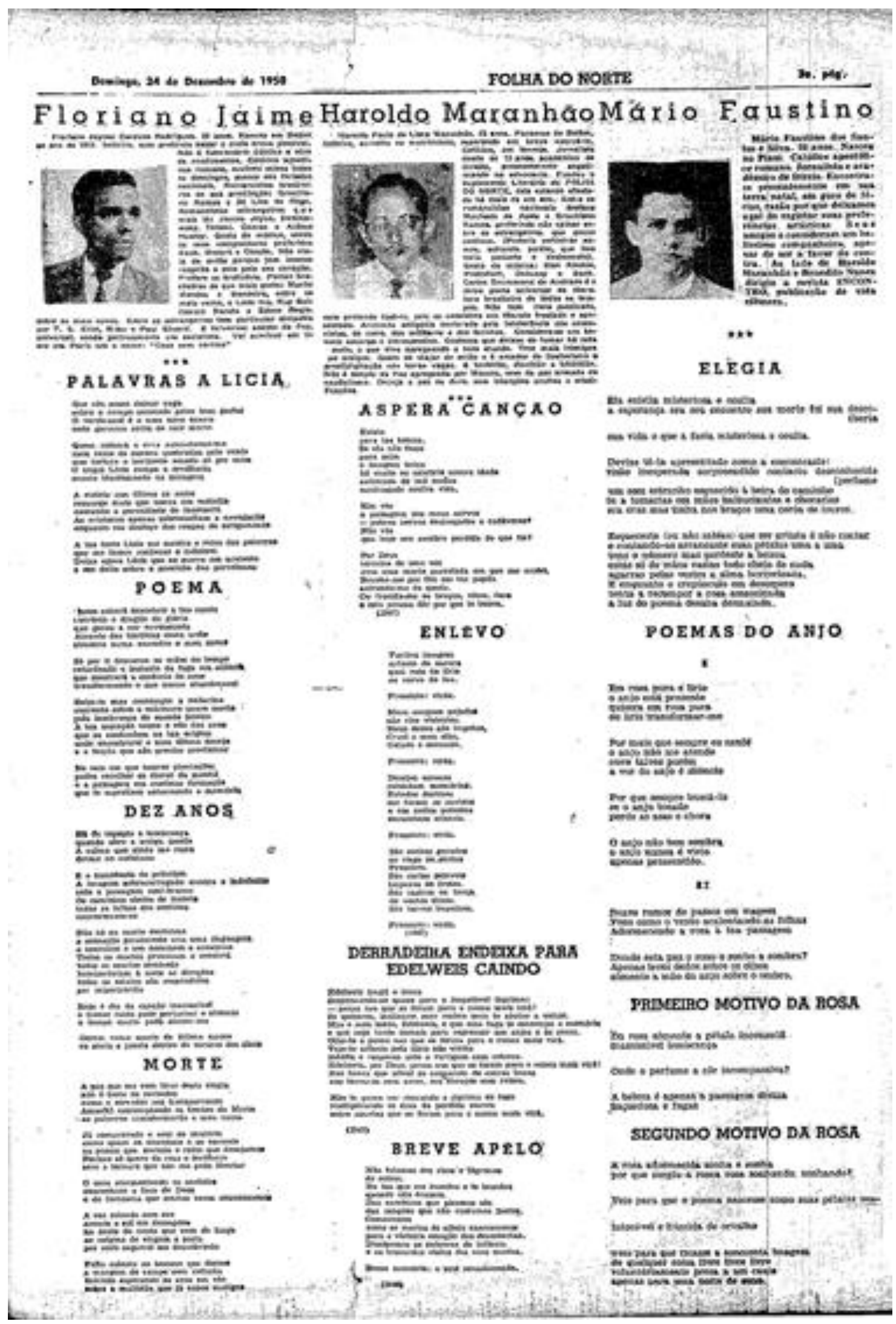

Fonte: Arquivo pessoal. 
Figura 7 - "Suplemento Arte-Literatura", de 24 de novembro de 1950, p. 4.

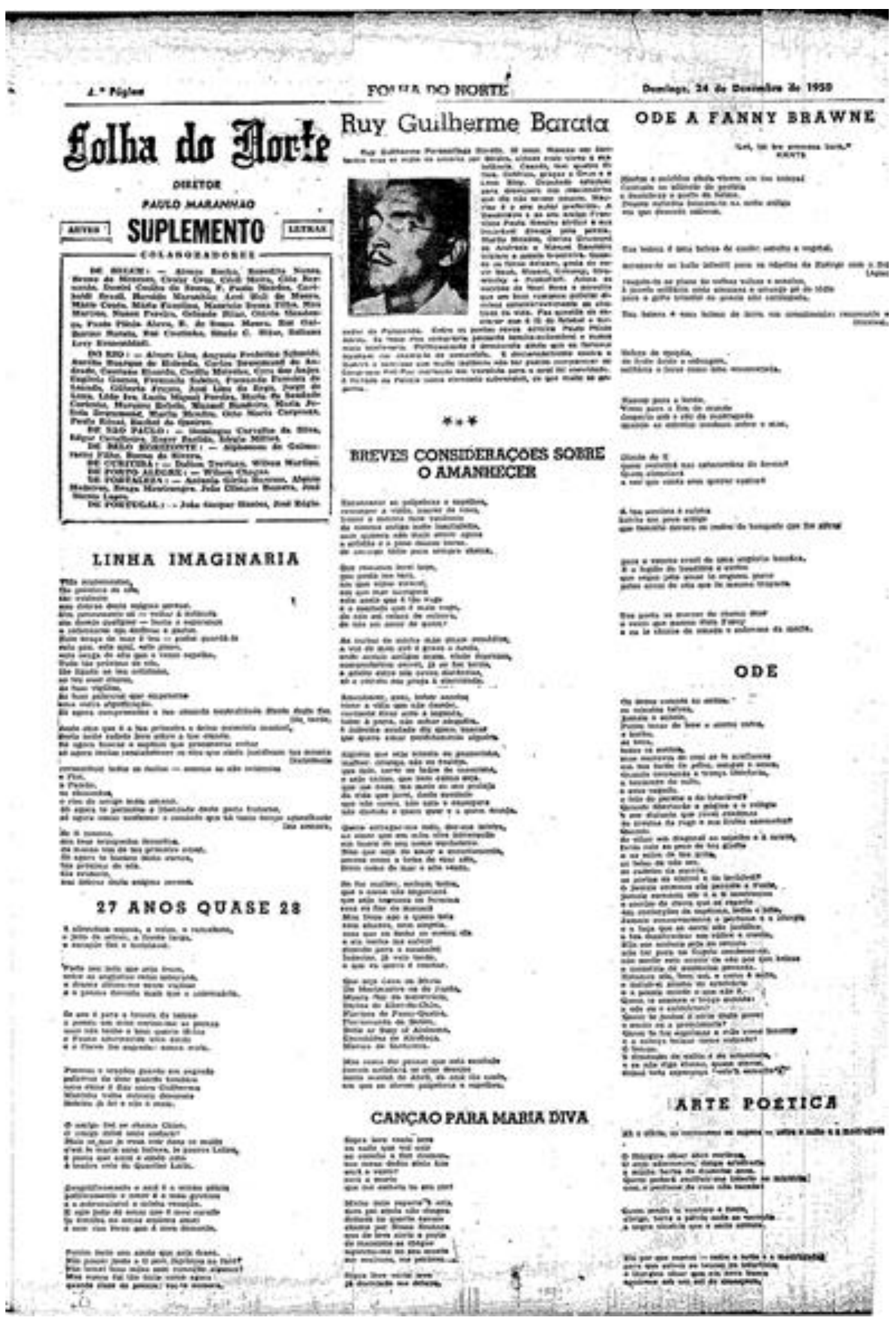

Fonte: Arquivo pessoal. 
É difícil reconhecer Max Martins na fotografia publicada na antologia (nessa figura copiada do jornal e muitas vezes recopiada), mas, segundo Francisco Queiroz (1912, p. 70), “A imagem mostra Max pronto para acender um cigarro, gravata em desalinho e certa pose de indiferença, contrastando fortemente com a postura séria de seus parceiros de verso nas demais fotografias da antologia". A foto escolhida faz par com a biografia do poeta, feita por Ruy Barata (1951, p. 2), inspirada na amizade que os unia, em 1950, é a de um poeta com 24 anos, iniciando sua trajetória, sem nenhum livro ainda editado, apenas com alguns poemas publicados no Suplemento da Folha do Norte.

\begin{abstract}
Max da Rocha Martins, 24 anos. Nasceu em Belém. Casado, tem uma filha, Maria da Graça. Católico apostólico romano. Marques Rebelo, Graciliano Ramos e Ciro dos Anos são, entre nós, os romancistas preferidos. Entre estrangeiros gosta de Proust e Gide. Bach, Mozart e Chopin são seus compositores. Comerciário. Carlos Drummond de Andrade, o absoluto entre os mais velhos, Ruy Guilherme Barata, Paulo Plínio Abreu e Ledo Ivo entre os mais novos. Gosta muito de Rilke e Fernando pessoa. Politicamente é socialista. Acredita na paz e acha um crime a bomba atômica. Seu primeiro ato poético foi ter sido preso aos 12 anos, como apedrejador de mangueiros. Trocou certa vez, em Abaetetuba, o livro do "imortal" Corrêa Pinto, por uma calça tropical. Tem um livro a publicar: $O$ estranho.
\end{abstract}

Dos cinco poemas da antologia - "Por quê?", "Varanda", "Poema", "O filho" e "Poema sem norte", dois não foram publicados no primeiro livro, $O$ estranho: "Poema" e "O filho", o que pode dar ao leitor uma noção da autocrítica de Max Martins, quanto à sua primeira leva poética.

Os poemas da Antologia:

\title{
POR QUÊ?
}

A meus irmãos

De onde vem esse sangue

Que não é vermelho, é róseo?

Esta sede de não parar em parte alguma,

Ter todos os portos nas mãos?

De onde é que vem este sangue?

De Vila Real?

De Fortaleza?

Do Porto?

Percorrerei todos os arquivos

Desejo saber porque só quero roupas brancas,

Gravatas berrantes. 
Por que minhas olheiras refletem mulheres nuas?

Por que amo, amo, amo?

Por que sou Max da Rocha Martins

E não Fernando de tal?

Por quê?

Por que José?

Por que Maria?

Por que Laís?

Por que te calas, Eurico?

\section{A VARANDA}

A Laís

O café que tinge a xícara

O leite que derramas na xícara

$\mathrm{O}$ riso que tens de cabelos molhados.

A água fria que espanta a noite

$\mathrm{E}$ a angústia das noites

$\mathrm{O}$ sol que bate na verde janela

E o vento que sacode a cortina bordada.

O jornal que noticia desastres

$\mathrm{Na}$ branda varanda

Onde o relógio domina.

A chaminé que respira

Cr $\$ 1.000,00$ em flor

O leite o beijo a rosa

A rosa que batiza a toalha.

\section{POEMA}

Neste momento está me faltando uma palavra mágica

Que não encontro nos dicionários

Nem em meu pai morto há dois anos

Nem no amor

Uma palavra mágica só

Uma só.

22 anos e o mesmo sol

O mesmo café todas as manhãs 
O mesmo beijo todas as noites

A mesma crise o mesmo dinheiro

As mesmas cadeias

Uma palavra só que não liberdade nem morte nem vida

Está me faltando uma coisa neste momento

Que eu não sei e jamais alguém saberá.

\section{O FILHO}

Grande "record"

Volteando teu corpo 21 anos

Hoje a vida repousa nos teus seios

Onde bebo vinho.

O vinho se transforma em tangos e bailados

Escorrendo no teu ventre

Nosso filho surgirá pedindo paz

Paz para que laves os teus vestidos.

Se me perguntares como será nosso filho

Está aí uma coisa de que vou me admirar.

É preciso que também te embriagues

E saias comigo por esses caminhos suando

Como quem quer o mundo para si

Tomemos o mundo e o sol dos caminhos

Até que surja o nosso filho pedindo paz.

\section{POEMA SEM NORTE}

É sempre quando se fecha a porta que desejo voltar

E a saudade já é este hoje que desprezo

Ante o beijo brotando da memória

Frio, mas vivo.

Caminho sem horizontes

Ao passado infalível.

Nunca prosseguir. Venho apenas.

Ferindo troncos, plantando marcos,

Ser como o mar, voltando sempre 
Sempre na praia.

Depois de tanto tempo - mais de cinquenta anos passados lembrava-se perfeitamente da reportagem e do artigo crítico que escrevera na época, com o pseudônimo de João Afonso. "Foi tudo uma ideia do Ruy Barata", contou, divertido. Ruy Barata, muito brincalhão, combinou com o Benedito que este escreveria um artigo crítico sobre os tais dez poetas paraenses e assinaria com um pseudônimo, como se fosse um crítico de fora, comentando a poesia da terra. E assim foi feito. Uma semana depois, o "Suplemento Arte-Literatura" de 31 de dezembro de 1950 publicou uma curiosa carta de um Sr. João Afonso ao redator do Jornal, dizendo-se crítico literário de passagem pela cidade e que, tendo lido a antologia dos "Dez poetas paraenses", publicada no "Suplemento" do domingo anterior, tomava a liberdade de mandar para o jornal, junto com a carta, algumas observações que a leitura lhe sugerira. E passava a comentar, um a um, todos os dez poetas, atacando inclusive a si mesmo. Entregando-se ao "ritmo irregular dos seus cochilos" e obedecendo à ordem do "movimento preguiçoso do olhar, num dia de domingo", o crítico transita de um poeta para outro, interligando-os por algum traço de estilo poético que os une ou distingue. Ao referir-se a Max Martins, inspira-se na fotografia do poeta:

Numa das fotografias aparece o sr. Max Martins acendendo um cigarro. Eis aí um motivo que ele não deixaria de aproveitar. A sua poesia tem o cotidiano como matéria-prima. Dela extrai a substância para os seus versos. É uma poesia perigosa, da qual a beleza pode escapar de um momento para outro, ficando, em seu lugar, apenas o pitoresco e o anedótico. Mas o que acho admirável e em virtude do que não tenho dúvidas quanto à possibilidade do poeta conseguir exterminar essa ameaça de uma vez por todas, é o profundo sentimento de viver que lateja nesses poemas. Que sabe até se não foi essa necessidade furiosa de viver que transparece em seus versos, que o levou a procurar a segunda vida que a poesia dá? A vocação para a vida teria forçado o aparecimento da vocação poética (AFONSO, 1950, p. 2).

Esse episódio desdobra-se ainda em duas outras críticas, uma escrita por Haroldo Maranhão, com o pseudônimo de Acrísio Alencar - "Dez poetas paraenses" -, e outra pelo poeta Floriano Jayme - "Ainda sobre dez poetas paraenses" -, ambas publicadas no Suplemento de 14 de janeiro 1951. Esse Suplemento traz também um artigo intitulado "Considerações sobre A peste", assinado por Benedito Nunes, seguido

\footnotetext{
$\$$ Essa entrevista com Benedito Nunes, aqui narrada, data de 2002 e foi publicada em Mário Faustino,
} uma biografia (CHAVES, 2004). 
do pseudônimo J. Afonso, entre parênteses, revelando sutilmente que o artigo crítico anterior era de sua autoria.

Logo depois desses dois números de antologias, a Folha do Norte deixa de incluir entre suas páginas, o já famoso Suplemento literário de Belém do Pará.

Talvez para suprir a falta do Suplemento, Max Martins e Benedito Nunes voltam à ideia de publicar uma revista literária cultural, como as que circularam no Paraná (Joaquim), no Rio Grande do Sul (Província de São Pedro) e no Ceará (Clã e José). Fundaram, juntamente, então, a revista Norte que, entre janeiro e junho de 1952, editou três "vitoriosos" números. "O número 3 de nossa pranteada revista estampava o seguinte anúncio extra e gratuito: Max Martins o extranho (sic com x) Ed. H. Barra" (NUNES, 2012, p. 162).

Então, em 1952, Max Martins publicou seu primeiro livro, $O$ estranho, com vinte poemas, dos quais quatorze já haviam sido publicados no Suplemento. Mais uma vez é Benedito Nunes que escreve as primeiras críticas do livro: o artigo "A estreia de um poeta", publicado na Folha do Norte, e a crítica-prefácio de $O$ estranho, texto que retoma na edição de Não para consolar, quarenta anos depois, quando faz uma espécie de crítica da sua crítica anterior, revendo algumas de suas afirmações do prefácio de 1952, que se tornou tema dos estudos sobre Max: "Max Martins - Mestre Aprendiz".

O parentesco da poesia de $O$ estranho - [...] - era com um Drummond muito anterior, o de Alguma poesia, Brejo das almas e José, conforme ousei afirmar em "A estreia de um poeta", artigo publicado em 52 no jornal A Folha do Norte, e com o qual me iniciei na crítica literária, depois de haver abandonado, por lúcida e acertada decisão, a arte poética (NUNES, 2001, p. 23).

Em dezembro de 1952, $O$ estranho de Max Martins, que concorria com $A$ palavra esquecida de Cauby Crus e Acrosticário e Carmes, de W. Soares Carneiro recebeu o prêmio "Vespasiano Ramos", do Concurso Anual de Literatura, da Academia Paraense de Letras (concurso lançado em setembro desse ano). A comissão julgadora da categoria poesia era formada pelos poetas Bruno de Menezes, Adalcinda Camarão e Jurandyr Bezerra.

Essa sede de não parar em parte alguma, que, desde 1950, o poeta descobre em suas veias e sobre a qual se questiona, esse desejo de "ter todos os portos nas mãos", a procura em "todos os arquivos", em todas as formas poéticas, já revelam que Max Martins faria de sua poética uma travessia, sempre em busca de novas formas e de novos padrões da linguagem. Talvez sentisse que a vida não era suficiente - e o 
profundo sentimento de viver que lateja em seus poemas, que seu primeiro crítico tão sabiamente intuiu, "o levou a procurar a segunda vida que a poesia dá".

Por que amo, amo, amo?

Por que sou Max da Rocha Martins

E não Fernando de tal?

\section{Por quê?}

O texto assinado legitima-se pelo nome próprio titular Max - Max da Rocha Martins (20 de junho de 1926-9 de fevereiro de 2009) -, e as palavras poéticas são testemunhas da diferença entre ficção e realidade (ou da sua semelhança). Max repentinamente passa a assinar simplesmente MAX, como se manuseasse um pincel japonês, a mesma assinatura que é a capa do seu livro: Poemas reunidos, 1952-2001.

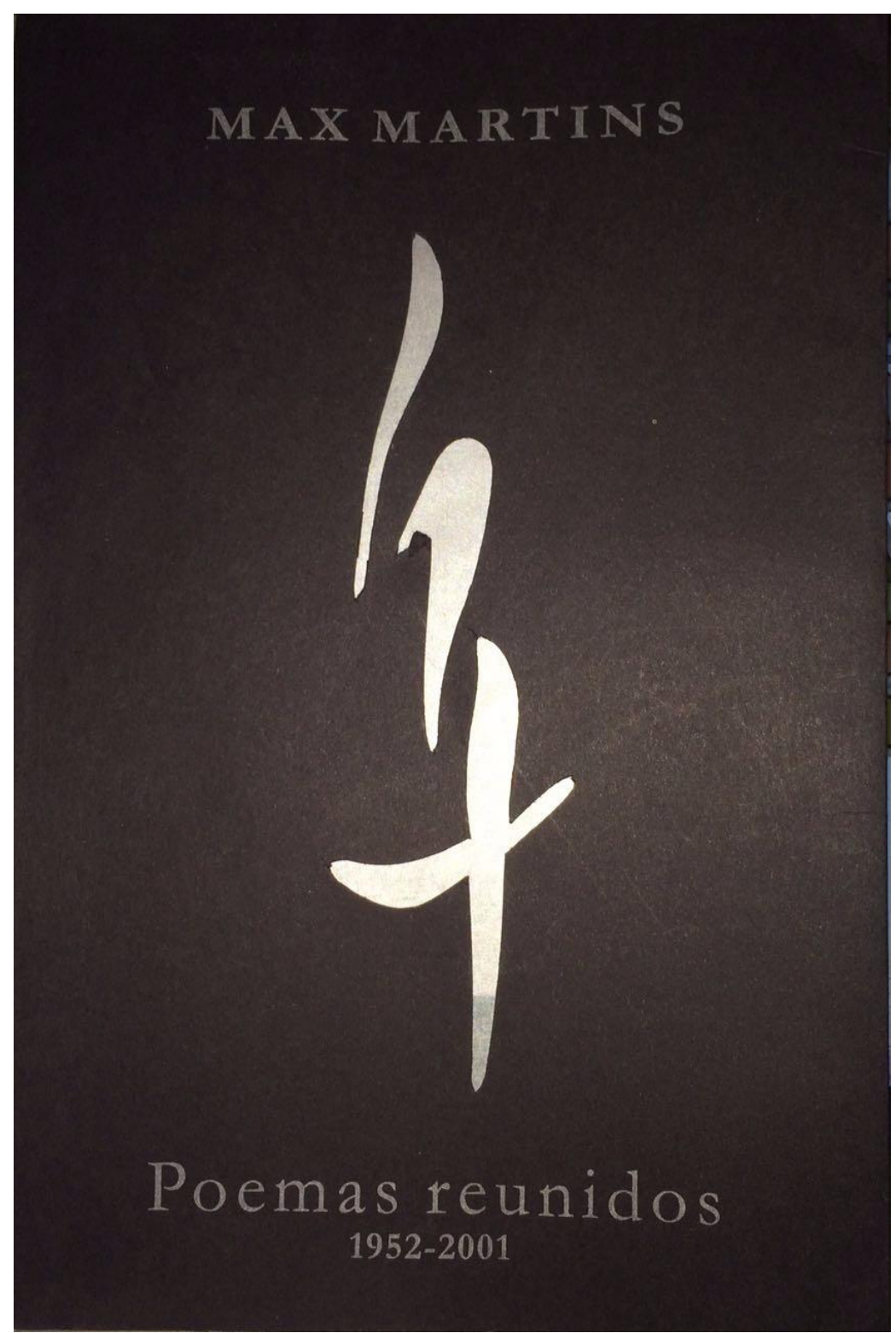




\section{REFERÊNCIAS}

AFONSO, João. Dez poetas paraenses. Folha do Norte, 31 dez. 1950, p. 1 e 3.

ALENCAR, Melissa da Costa. 1952: a poesia de $O$ estranho de Max Martins. 2011. 247

f. Dissertação (Mestrado em Letras) - Universidade Federal do Pará, Belém, 2011.

MARTINS, MAX. Posição e Destino da Literatura Paraenses. Belém, Suplemento Artes-Letras. Folha do Norte, 7 dez. 1947.

MENEZES, Bruno de. Posição e Destino da Literatura Paraenses. Belém, Suplemento Artes-Letras. Folha do Norte, 2 nov. 1947.

NUNES, Benedito. Prefácio Max Martins, mestre-aprendiz. In: MARTINS, Max. Poemas reunidos, 1952-2001. Belém: UFPA. 2001. p. 19-45.

NUNES, Benedito. Devoção à poesia. In: O amigo Chico fazedor de poetas. Belém: Secult, 2001. p. 37-38.

NUNES, Benedito. Francisco Paulo Mendes, para além da crítica literária. In:

$O$ amigo Chico fazedor de poetas. Belém: Secult, 2001. p. 15-24.

NUNES, Benedito. Nossos encontros. In: Do Marajó ao arquivo: breve panorama da cultura no Pará. Belém: Secult: UFPA, 2012. p. 161-164.

QUEIROZ, José Francisco da Silva. Por uma História da recepção da obra de Max Martins. 2012. 233 f. Dissertação (Mestrado em Letras) - Universidade Federal do Pará, Belém, 2012.

SANJAD, Nelson. Histórias de fracassos. In: NUNES, Benedito. $O$ amigo Chico fazedor de poetas. Belém: Secult, 2001. p. 101-102. 